\title{
ESPEJOS HIPERREALISTAS: LOS TESTIMONIOS AL ÓLEO DEL HISTORIADOR EXEQUIEL MARTINEZ
}

\author{
Rosana Guber ${ }^{1}$
}

Malvinas fue el conflicto bélico internacional de los argentinos en el siglo XX, la única contienda en que la Argentina estuvo involucrada como contendiente directo contra las fuerzas militares de otro estado nacional, Gran Bretaña. Ni bien el conflicto bélico, aunque no el diplomático, llegó a su fin el 14 de junio de 1982, diversos sectores de la sociedad política, civil y militar del país comenzaron a elaborar este episodio con voces, imágenes y silencios. Así, las conmemoraciones escritas, orales y ceremoniales hicieron sus caminos por las ciudades y los pueblos, por la prensa escrita y audiovisual, por la literatura y el ensayo, renovando cada año entre el 2 de abril y el 14 de junio las memorias de la guerra y manteniendo viva la causa de soberanía pendiente por el archipiélago sudatlántico.

Las imágenes fijas (fotografía) y móviles (filmaciones) tomadas por argentinos y británicos en el momento de los hechos, le dieron visualidad a las representaciones argentinas sobre Malvinas. Pero con el correr del tiempo dichas imágenes se incrementaron, tanto porque sus autores decidieron hacerlas públicas, especialmente en las fechas conmemorativas, como porque un tipo distinto de imagen hizo su aparición. Las imágenes pictóricas ilustran hasta hoy los artículos en periódicos y en volúmenes sobre distintos aspectos de la contienda. Sus primeras manifestaciones se hicieron públicas en uno de los primeros volúmenes que se editaron en la inmediata postguerra. En marzo de 1983 una poderosa empresa editorial periodística-Abril-lanzó con el sello del semanario de interés general Siete Días, una compilación de testimonios escritos por los protagonistas de la batalla aérea ${ }^{2}$.

\footnotetext{
${ }^{1}$ Instituto de Desarrollo Económico y Social, Buenos Aires, Argentina.

${ }^{2}$ Buena parte de las imágenes que aquí presentamos, fueron publicadas posteriormente a la composición de este artículo en el volumen de La aviación argentina en el arte de Exequiel Martínez (Martínez 2012 a) con motivo de cumplirse el centenario de la Aviación Argentina y, además, el $30^{\circ}$ aniversario del Bautismo de Fuego de la Fuerza Aérea Argentina (en Malvinas); ambas conmemoraciones tuvieron lugar en el año 2012. Presento aquí las imágenes publicadas y sus correspondientes referencias.
} 


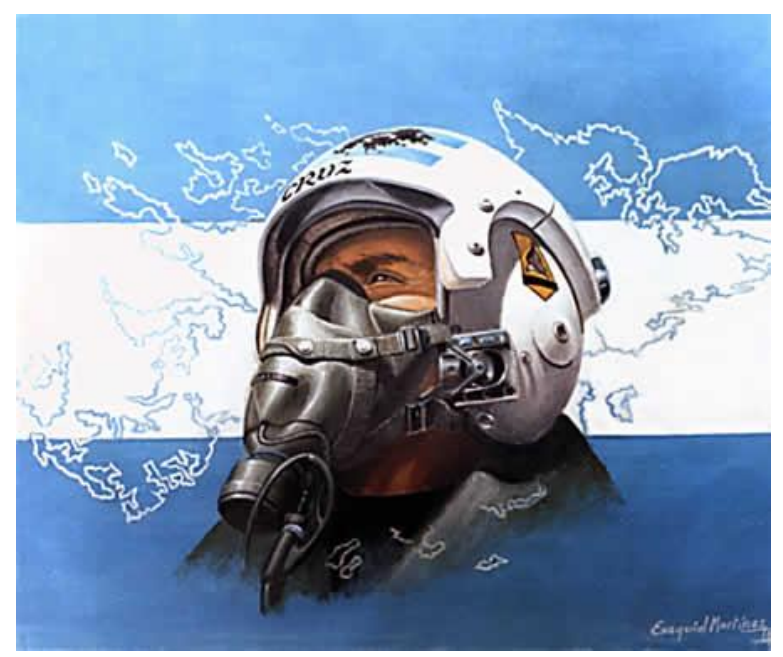

Tapa de Dios y los halcones de Pablo M. Carballo, 1983.

El volumen fue concebido y organizado por el entonces Capitán Pablo M. Carballo, que en Malvinas se desempeñó como jefe de la escuadrilla Cruz perteneciente al Escuadrón I del Grupo 5 de Caza de A4B Skyhawks, con sede en Villa Reynolds, San Luis, y que durante el conflicto operó desde las bases continentales de Río Gallegos $\left(1^{\circ}\right.$ de mayo al 8 de junio) y de San Julián ( 9 al 14 de junio). En su interior y desde la tapa, el volumen está ilustrado con fotografías tomadas durante la guerra y con escenas pintadas de combates aéreos y aeronavales. El autor de esas imágenes, copias de cuadros de porte mayor, era un capitán de reserva nacido en Monteros, Tucumán, en 1939.

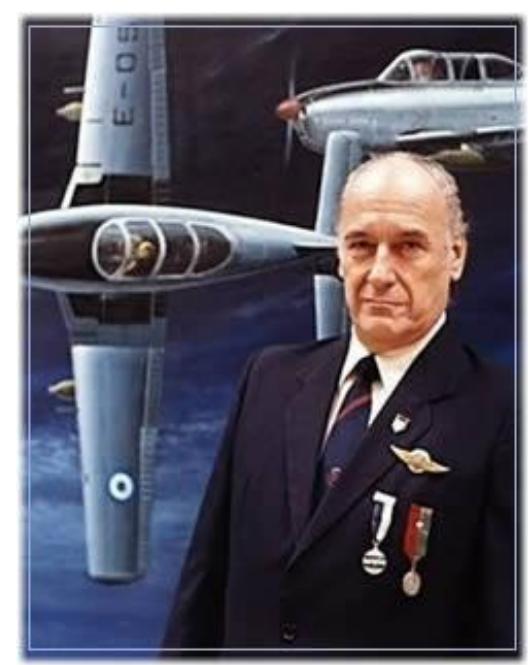

Exequiel Martínez, 2012. Cap (R) Exequiel Martínez. 
Había ingresado en 1958 a la edad de 19 años, a la Escuela de Aviación Militar en Córdoba donde vivió parte de su infancia y su adolescencia. Egresó de la EAM en 1963 como piloto militar de la promoción 28. Fue asignado a helicópteros después de un accidente a bordo de un avión Mentor en la base de Mar del Plata, en 1965. Dejó la Fuerza Aérea 14 años después, en 1972. Desde su retiro fue contratado por varias compañías y por el gobierno nacional como helicopterista; también condujo el helicóptero presidencial.

Conocí a Exequiel Martínez en Resistencia, Chaco, en 1991, cuando aún trabajaba para la gobernación, cargo que ocupó durante 20 años (1976-1996) asistiendo y rescatando poblaciones inundadas y aisladas, y colaborando con la mensura del Impenetrable. En 1996 y a los 57 años de edad se retiró de la actividad aérea y se dedicó principalmente a la pintura, combinada con su otra pasión, armar automóviles. Los dos talleres (el artístico y el mecánico) eran contiguos. De su atelier brotaban fotos y esquemas de aeroplanos de distintas épocas, que a menudo circundaban la tela de un cuadro en pleno proceso de producción.

Yo tenía varias razones para querer conocerlo. En 1991 y en 1992 traté de obtener materiales sobre la aviación en Malvinas. Para esto fui al Edificio Cóndor, sede del Estado Mayor de la Fuerza y donde funcionaba la Comisión de Historia y Evaluación BANIM (Batalla Aérea por las Islas Malvinas) que presidía un viejo cazador, Francisco Pío Matassi. Para ese entonces y rozando la primera década del conflicto, los cuadros de Martínez en original y en reproducciones, comenzaban a tapizar oficinas y despachos, además de libros y artículos periodísticos, calendarios, folletos, postales y afiches. Pero Exequiel no es el único pintor aeronáutico. En 1983 la revista argentina bimestral de cuestiones aéreas y espaciales Aeroespacio publicó una pintura suya para ilustrar un artículo sobre las acciones bélicas en el Estrecho de San Carlos. En 2005 publicó un artículo específico sobre su obra, como parte de la serie "Galería de Arte", sobre artistas aeronáuticos argentinos como Carlos García, Alfredo Campos, Marcelo Morard y Allan O’Mill, y el dibujante Oski (2004-2005). También publicó, en el último número de 2005 un artículo con lámina central desplegable sobre el primero de tres murales/paneles con la historia de la Fuerza Aérea en pequeñas imágenes. En 2009 y en 2012 se publicaron otros dos artículos sobre su obra. 
Ciertamente, los cuadros de Martínez le dieron imagen pública a la Fuerza Aérea que se los compraba, a menudo por encargo, para exhibirlos en nuevas conmemoraciones, y como obsequio a instituciones y a personalidades de la Argentina y del exterior (como el mural sobre la OACI, Organización Aeronáutica Civil Internacional, ver www.exequielmartinez.com.ar o Martínez 2012a). Junto con la gestión de Matassi y los libros de Carballo, las pinturas de Martínez fueron decisivas para difundir e individualizar las realizaciones institucionales de la aeronáutica militar en 1982 (Guber, 2007).

Los cuadros contienen escenas aeronáuticas con aviones de distintas épocas, en distintas funciones, maniobras y contextos. Generalmente representan situaciones en vuelo individuales, de secciones o escuadrillas, fuertemente coloridas, en óleo y pintura acrílica, y de tamaño "clásico" (1,20 x 0,90 m.). La obra con más de 300 piezas que él guardó fotografiada en negativos o digital antes de entregarlas, comprende aeronaves históricas, la batalla aérea de Malvinas, los retratos de personalidades de la aviación argentina, y pinturas de cuerpo entero de los oficiales, suboficiales y soldados caídos en 1982, además de los mencionados paneles.

Mi acercamiento a Martínez en 1991 estuvo enmarcado por cierta perplejidad. Sus cuadros parecían fotos, por lo minuciosos y detallistas. Me llamaba la atención esta forma de arte tan apegada a la imagen convencional, pareciendo que no quería apartarse ni un milímetro de la imagen real. Pero entonces, ¿dónde estaba el arte y dónde radicaba la creatividad del pintor? O, en todo caso, ¿por qué pintar aviones y combates en la era de la fotografía y la filmación? ¿No era esto una clara redundancia con sabor a derroche de preciosismo? Algunos observadores, incluso pertenecientes a la institución aeronáutica, contestan estas preguntas desde una perspectiva práctica y especulativa: la Fuerza Aérea habría encontrado un artista para embellecer sus misiones y servirle de propaganda militar. En contrapartida, Martínez le vendería sus cuadros a la institución. Entonces aquellas pinturas podrían explicarse como el producto de la conveniencia política (especialmente tras la derrota bélica) y el mecenazgo.

Aunque fueran en parte ciertas (Martínez vendió la mayoría de sus cuadros a la Fuerza Aérea, y ésta los mostraba, distribuía y/u obsequiaba), estas respuestas simplifican una actividad que tuvo muchos más protagonistas y se desarrolló en más dimensiones que sólo la comercial y la de "imagen institucional" que, como veremos, 
no son las centrales de su obra. En todo caso, para entender cómo y por qué los cuadros de Martínez terminaron tapizando los pasillos, museos, oficinas y despachos, además de hacer su propio camino por los puestos del comercio informal de imágenes en láminas y afiches, creo más fructífero y genuino buscar las respuestas en el pintor, en los pilotos y en la cotidianeidad aeronáutico-militar. Esto me distancia de los enfoques propios de las artes comparadas, la distinción de estilos y la ponderación de géneros pictóricos, pero también me aleja de las miradas escépticas que buscan el puro negocio o el mensaje ideológico detrás de la obra de arte.

Mi aproximación va más en el sentido del análisis que Carlo Ginzburg hizo del tríptico El Bautismo, El ciclo de Arezzo y La Flagelación de Cristo, de Piero de la Francesca. En El enigma de Piero (1985) el historiador italiano reconstruyó las condiciones de encargo y de uso de estas pinturas, y así puso de relieve su sentido práctico (que, en aquel caso, consistía en una propuesta de alianza en contra de los Turcos). Ginzburg explica, al comenzar su libro, que no analizará los aspectos formales de las pinturas dado que no es un historiador del arte. Si bien esto es una seria limitación, sostiene que pueden decirse otras cosas interesantes. En mi caso, y siendo contemporánea de Martínez y del acontecimiento que él pintó (la batalla aérea por las Islas Malvinas) tengo la posibilidad de hacerle consultas acerca de sus cuadros, y ver a éstos en interacción directa con sus retratados y otros observadores. Puedo descubrir, así, las otras dimensiones a las que sus obras nos reenvían.

Por eso, cuando lo reencontré en 2009 en la ciudad de Unquillo, su residencia actual en la provincia de Córdoba, abandoné la pregunta por el valor artístico de la pintura en vez de la foto, y comencé a explorar el significado teórico y práctico que sus pinturas sobre las acciones en Malvinas suscitaban para él y para otros miembros de la Fuerza, estuvieran o no retratados en ellas. Traté entonces de reconstruir la perspectiva del pintor (qué entendía que hacía al pintar, cómo pintaba y cómo describía su acción de pintar, cómo ponderaba sus pinturas y hablaba de ellas) y la de algunas personas que, casualmente o no, me hablaron de sus obras. En estas páginas quisiera mostrar que la creatividad de Exequiel Martínez no reside sólo en su dimensión artística, ciertamente innegable, sino en que sus cuadros son constitutivos de la experiencia bélica de los pilotos militares y, particularmente, la de los pilotos de la Fuerza Aérea que participaron en la batalla aérea de Malvinas entre el $1^{\circ}$ de mayo y el 14 de junio de 1982. Si así 
fuese, limitar un estudio de las pinturas de Martínez al de las obras de arte sería conceptualmente inapropiado. Tanto Exequiel como sus camaradas aeronáuticos toman sus cuadros como otra cosa y aquí quisiera mostrar como qué.

Para ello me valdré de mis conversaciones telefónicas, electrónicas y presenciales con Exequiel en Resistencia (1991) y en Unquillo (en su casa o almorzando en el Club local, 2009-2012), y con miembros de la Fuerza. También emplearé artículos periodísticos aeronáuticos (principalmente de Aeroespacio) y de la prensa gráfica, y mi visita a distintas dependencias institucionales del Estado Argentino como el Ministerio de Defensa, el edificio Cóndor, comando general de la Fuerza Aérea, la Dirección de Estudios Históricos, la V Brigada Aérea de Villa Reynolds, San Luis; la sede social o "Círculo de la Fuerza Aérea", la Escuela de Aviación Militar de Córdoba, y el Museo de Malvinas y la Sala de Honor, ubicados en el Cuerpo de Cadetes de dicha Escuela.

Como me dijo el Comandante Crespo, el comandante en jefe de la Fuerza Aérea me dice: -Martínez, su responsabilidad es la siguiente: en el año 2200 yo no voy a estar, nadie se va a acordar de mi, pero va a haber un libro o una película o un video, no sé qué usarán en esa época los alumnos, que diga: "Fines de siglo pasado: Bautismo de fuego de la Fuerza Aérea, cuadro de un pintor de la época". Y va a estar Usted. En el año 2200 va a estar ese cuadro, así que espero que lo haga bien (se ríe). Estas son las responsabilidades que me ha conferido la Fuerza Aérea para hacerlo (Resistencia, 1991).

Aunque Martínez venía pintando desde chico, Malvinas abría un panorama nuevo para la Fuerza Aérea, ya bastante diferenciada del más relativo éxito de las otras dos fuerzas armadas que habían lanzado el plan de recuperación, el Ejército y la Armada. Tal como Martínez la entendía, la misión que le había sido encomendada por la conducción institucional no era artística sino de documentación histórica: fijar en imágenes el apabullante desempeño aeronáutico en su bautismo de fuego. Esa fijación tendría como soporte una pintura, pero esta pintura debería cumplir con ciertas condiciones que, como veterano pintor de aeronaves civiles y militares, Exequiel había aprendido. Pero ¿por qué pedirle a un pintor, y no a un fotógrafo, la documentación del presente, si la fotografía y la filmación son documentos más fehacientes?

Aunque éste no era estrictamente el caso, ya que Martínez también era aficionado a la fotografía, fotografía y pintura se planteaban, para él, en seria competencia. 
orgánica inestable que tiene una duración de 30 años. Las fotos de casi todo el mundo del casamiento y todas esas cosas, nuestros padres, quedan borradas. Las diapositivas están blancas. Menos todavía que las fotografías impresas. Entonces ¿qué es lo que quedan de nuestra época para el futuro? Los cuadros al óleo han demostrado con Leonardo y Miguel Ángel que duran siglos, entonces el mensaje futuro de los cuadros al óleo de qué es lo que la Fuerza Aérea hizo. Y ahora estoy utilizando en los últimos la técnica del acrílico que permite un secado rápido y son compuestos mucho más modernos, pero ya los óleos han demostrado su perduración a través de los siglos. Es una forma de trascender; entonces yo uso la mejor tela que es de lino que es la que es más inalterable por el tiempo, que han demostrado los pintores de la antigüedad, el lino perdura que es impresionante. Hay telas egipcias hechas con lino. Entonces las telas son de lino las que uso yo y la mejor pintura, por una responsabilidad de mandar un mensaje al futuro, o sea, estamos haciendo historia (Resistencia, 1991).

Visto el soporte en materiales durables, la misión también se refiere a las representaciones icónicas que suponen la selección y modelado de los hechos que deben trascender, lo cual conlleva necesariamente algún grado de "creación" o, dicho de otro modo, de "subjetividad".

Hace años la Fuerza le encomendó un retrato de Manuel Belgrano. Entonces Martínez se puso a indagar en fuentes de la época.

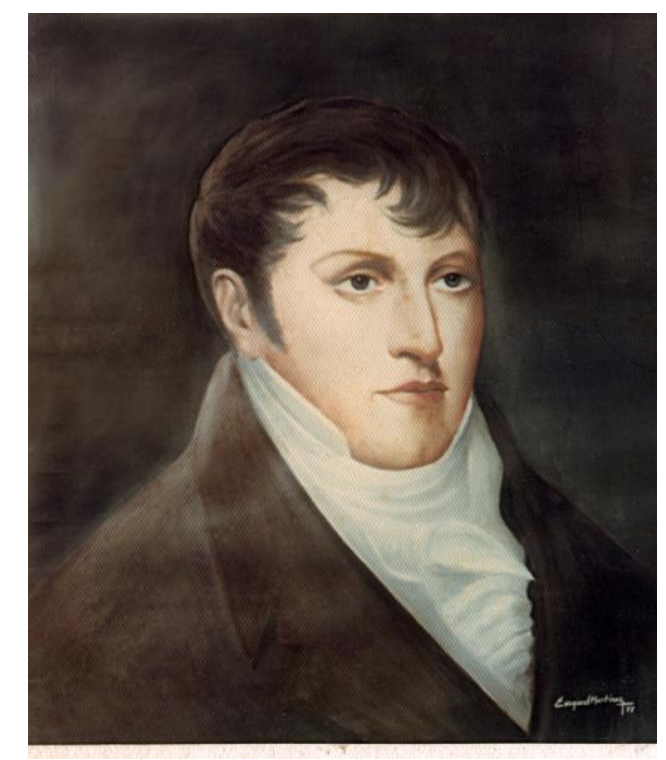

Martínez 2012a. Retrato de Manuel Belgrano.

Cuando yo hago la reconstrucción histórica de Manuel Belgrano me encuentro con la descripción oral de M.B. que es rubio ojos azules pelo ensortijado. Lo hago a Belgrano y me dicen ¡No! Pero todo el mundo ya lo conoce a Belgrano de pelo castaño y ojos marrones porque un pintor de la época lo pintó así. Entonces eso refuerza el concepto de que nosotros hacemos la historia, la historia no es como nos relatan, habrá ocurrido de otra forma, pero para nosotros es como nos cuentan. Lo tuve que hacer marrón (al 
pelo) porque si no nadie sabía que era Belgrano. Y ya el pintor que pintó ya lo pintó a Belgrano con pelo castaño y de ojos marrones y ya quedó para la historia así, y no es así. La descripción oral de los escritos de la época de la gente que lo narra cómo era. Dice: hombre de mediana estatura, de tez pálida, de ojos azules y pelo ensortijado, tenía rulos. Y aquí tiene pelo lacio. Y ya nos quedó así. Ya no hay forma de cambiarlo. O sea, nosotros los pintores hacemos la historia.

Exequiel estaría, en cuanto a Malvinas, en la posición de un contemporáneo capaz de "hacer la historia" a su gusto. Pero no es tan libre porque su pintura debe responder a la misión encomendada; no puede dar rienda suelta a su creatividad. Menos aún si responde afirmativamente a la invitación de Carballo de ilustrar un libro de pronta aparición y que se agota velozmente. En marzo de 1983 se imprimía Dios y los halcones como suplemento-libro de la Editorial 7 Días. La tapa y varias de sus ilustraciones cuentan con pinturas de Exequiel y fueron vistas por algunos de los protagonistas de las escenas allí representadas.

Si un mínimo margen de "creatividad" debe necesariamente acompañar a toda pintura (como también a todo texto), en el caso de los cuadros históricos esa creatividad debe poder representar "adecuadamente" el pasado, es decir, debe representarlo de un modo en que sus contemporáneos se encuentren reconocidos, o bien, si no hubiera contemporáneos, de un modo que sea aceptable según los cánones historiográficos y de la representación. En este sentido, Martínez afronta el mismo desafío que los historiadores que reconstruyen el pasado distante tanto como el pasado reciente. Lo que dice el africanista J.D.Y. Peel de la historia oral puede aplicarse a las obras de Martínez y también a la historia académica. Para él la historia oral depende de "convicciones sustanciales de los miembros de la sociedad en relación a partes del pasado, así como de ideas generales acerca de lo que es históricamente plausible" (Peel, 1984: 112). Siendo que buena parte de las obras de Martínez estarían destinadas a la institución aeronáutica militar, era imprescindible que sus criterios de belleza y de representación pictórica estuvieran muy próximos a los criterios de plausibilidad tanto de quienes detentaban el oficio de aviadores, como de los conductores de la institución. Los cuadros de Martínez cuentan la historia de la Batalla Aérea y del Bautismo de Fuego de la Fuerza Aérea Argentina, pero no la cuentan en orden ni lo cuentan todo (como tampoco lo hacen las historias convencionales). Veamos, entonces, qué requirió el pintor para hacer creíbles sus pinturas y cómo elaboró sus criterios. 
El primer criterio que a su juicio es determinante es su propia experiencia no como pintor sino como piloto. Con la noticia del desembarco argentino en Port Stanley, Martínez se presentó como Capitán de Reserva y fue incorporado con el "nombre de guerra Chaco" a bordo del helicóptero Bell 212, con asiento en la Base aérea de San Julián. En su CV consta que desarrolló desde allí varias tareas como trasladar “explosivos y patrullas de infantería, realizó patrullaje de costas, búsqueda de comandos ingleses, reconocimiento de buques, acompañamiento de aviones de combate en emergencia a sus regresos de Malvinas". Como vimos, Martínez era egresado de la EAM y era piloto militar

[...] no soy buen pintor, soy buen piloto. Y pinto lo suficiente como para representar lo que los pilotos hacen con conocimiento de cómo lo hacen. $\mathrm{O}$ sea, no es meritoria mi pintura; es meritoria mi aeronauticidad volcada a representar lo que hace la gente y la gente no necesita que mis pinturas sean las mejores pinturas del mundo. Lo que necesitan es que mi pintura represente lo que ellos hacen.

Para saber lo que "ellos hacían en Malvinas", el segundo criterio es la proximidad témporo-espacial con los hechos, cosa que lograba con su presencia en misiones de rescate y salvamento en una base en operaciones.

Muchos pilotos, luego de hacer el informe de sus misiones, relataban las mismas al "pintor de las cosas nuestras". Estas narraciones más las aportadas por el Capitán Pablo M. Carballo permitieron que narrara la historia del Bautismo de Fuego de la FAA en imágenes.

Exequiel siempre me contó que ni bien regresaban de sus misiones, los oficiales reportaban a oficiales de inteligencia acerca de lo que habían hecho y visto. El oficial consignaba lo expuesto en planillas o Informes, que están archivados en la Dirección de Estudios Históricos de la FAA. A continuación, se encontraban con él y también le contaban, mate por medio, sobre todo si habían pasado por una situación excepcional como sobrevivir a un ataque naval o aéreo, o atacar con éxito un objetivo naval o terrestre. Exequiel bosquejaba alguna escena y la iba corrigiendo en el diálogo con su interlocutor. Esa escena era un corte en el tiempo que abarcaba una misión, y que él elegía, pero esa elección dependía del énfasis del piloto en su relato acerca de lo que acababa de vivir.

En uno de sus últimos cuadros, Exequiel cumplió finalmente con una vieja promesa. Mario Callejo era entonces 1er teniente de MV y acababa de volver de una 
misión a la base de San Julián. Exequiel lo recordaba como "compinche guitarrero", "muy buen camarada y esa tarde vino transparente a nuestra mesa. El julepe de Mario había sido grande y mi servilleta chica”.

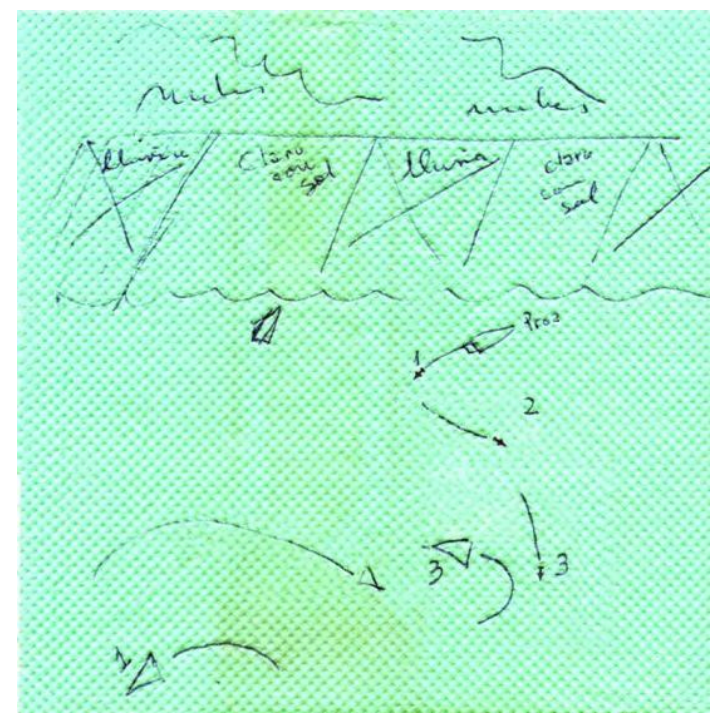

Martínez 2012b. Esquema de la acción.

No sabés lo que me pasó [...] después de lanzar mis bombas en San Carlos escapé rasante hacia el Norte buscando el mar. La visibilidad estaba reducida por techos bajos y chaparrones. Después de un tramo al frente para salir de los peñascos de la costa y entre la bruma al comenzar el viraje a mi izquierda buscando el oeste para poner rumbo a San Julián, las vi. Allí estaban... Las siluetas de las misilísticas se recortaban en la penumbra contra la luz que al fondo se colaba entre las nubes. Por el rabo del ojo pude ver el relámpago y después el fogonazo del lanzamiento del misil.

Instantáneamente en mi mente se formó la imagen de los rostros saliendo a cubierta para ver ese seguro derribo del "argie" que escapaba como un cobarde. Me hirvió la cara de bronca y perdido por perdido enfrenté decidido a la nave para morir como un guerrero... Para no darles el gusto de que me vean morir huyendo como un cobarde. Y entonces el milagro... en esa fracción de segundo vi el anillo brillando recortado contra la silueta oscura del buque... ¡Es el misil!....lo pude ver. Para disipar la duda, puse palanca a la derecha y el anillo obedeció desplazándose hacia la derecha. No hay duda, es el misil. La computadora del director de tiro de la nave lo mandaba al punto de encuentro con mi avión en ese rumbo tomado. Mantuve la presión de comandos a la derecha todo lo que pude hasta que me pareció inminente la colisión. Entonces con todas mis fuerzas obligué al avión a hacer un violento viraje a la izquierda y mirando el mar porque iba rasante esperé la explosión. No pasó nada. Nivelando el avión, como ya tenía las naves muy cerca les hice con la mano izquierda sobre el codo derecho el clásico corte de manga. No creo que lo hayan visto pero ese gesto fue un buen desahogo para mí. 
El lápiz de Exequiel volaba sobre lo único que tenía a mano para registrar los datos del relato, una servilleta de papel sobre la mesa. Estaba registrando una maniobra similar a una gambeta de Maradona. (Martínez 2012).

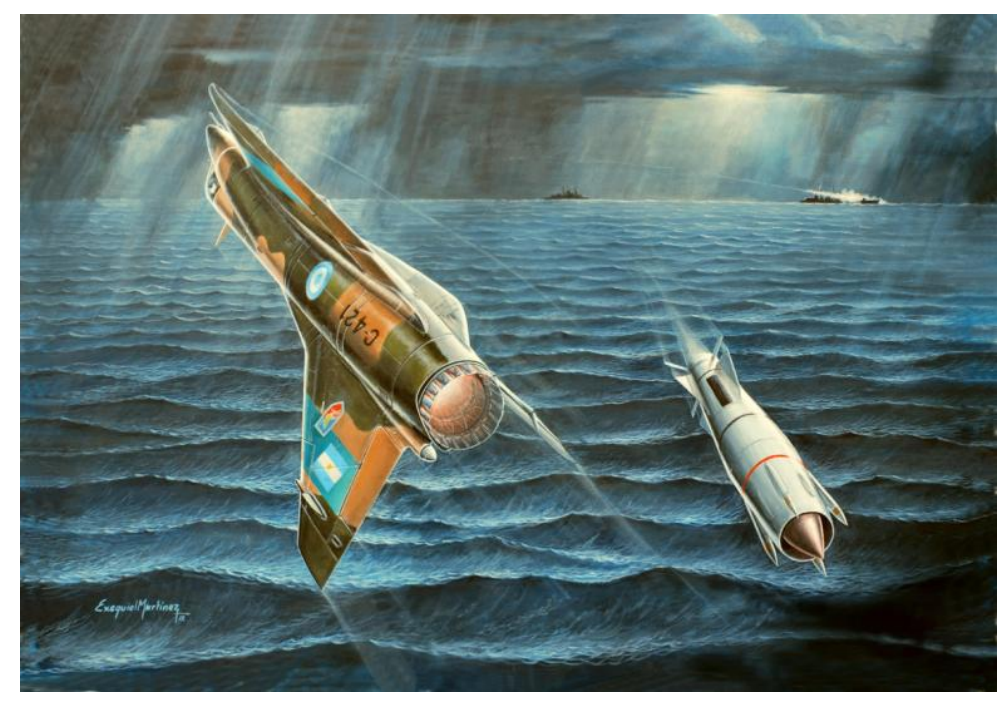

Martínez 2012b. M-V de 1er Ten. Mario Callejo esquivando el misil.

Exequiel pudo reconstruir la escena y hacer el cuadro prácticamente 30 años después de ocurrida su escena porque encontró la servilleta y también porque se encontró con el protagonista de la historia, quien le hizo, en el ahora fugaz intercambio, de recordatorio. En cierto modo, con o sin 30 años de dilación, el cuadro del M-V de Callejo no era muy distinto de otros diseñados poco después de terminada la guerra. Al estar basado en San Julián, Exequiel pudo acceder por testimonios directos e inmediatamente posteriores, sólo a las misiones de los A-4C y a un escuadrón de Dagger, pues el otro estaba en Río Grande; también a las misiones de los A-4B que fueron relocalizados de Río Gallegos a San Julián el 8 de junio. Pero varios de sus cuadros representan, además, acciones de los B emprendidas previamente a esta fecha como los ataques a las fragatas Glasgow (12/5), Argonaut (21/5), Ardent (21/5), Antelope y Coventry (25/5). Lo mismo sucede con la única misión conjunta de aviones de combate de la Armada y de la Fuerza Aérea y una de las más recorridas por Martínez (con 6 ó 7 piezas). La escuadrilla de A-4C y el par de Super Etendard de la Armada salieron de Río Grande, Tierra del Fuego, a la localización del portaaviones HMS Invincible, y regresaron al mismo punto de partida, no a San Julián. Así, disponer del relato sobre la acción inmediata se aplicó a algunos cuadros pero no la mayoría. 
¿Cómo resolvía esta falta de inmediatez? Con la narración corporal de los pilotos. En sus reuniones posteriores con los protagonistas de la acción a representar, generalmente algún o algunos miembros de la escuadrilla afectada le contaban lo sucedido pero no sólo con palabras. Además de transcribir en el papel las ubicaciones y las secciones generales del cuadro, el relato presencial permite agregar el movimiento y la intención de los aviones representados que los pilotos suelen representar con sus movimientos de brazos, manos y cara, haciendo la analogía entre la nariz del avión y la nariz del narrador, los brazos y manos como alas, a veces, y a veces como el recorrido de la aeronave. Para cruzar la gigantesca brecha que media entre los datos fríos de la acción y la "reconstrucción" de la escena, Exequiel necesitaba escuchar a los jóvenes oficiales en forma presencial.

Ya en el taller, Martínez pasaba a la tela y a concentrarse en los protagonistas de sus pinturas: los contendientes.

El realismo de los aviones. Yo le voy a mostrar una carpeta de aviones Pucara para que usted se dé cuenta. Todas estas fotografías, armamento de Pucará. Esta foto la tomé yo personalmente, Pucará volando. Detalles del motor lado derecho del Pucará. Detalles de cabina lado derecho. Detalles de la parte derecha del avión. Detalles del frente. Avión tomado de frente. Están tomadas en el suelo. Este es costado izquierdo del avión. Esta es la fábrica militar de aviones prototipos, de cuando se estaban haciendo. Es incontable. Yo tengo cientos de fotos si no miles de fotos de Pucará de todos los tipos y tamaños, en distintas posiciones. Esto es todas las partes del detalle de la zona entre el plano y el empenaje, el fuselaje, costado izquierdo, donde está la matrícula, donde están los números, cómo están dibujados los números, cuál es la forma de los números de la matrícula, la toma de nivelación del avión, los ejes de nivelación, la antena, todos los remaches, la cantidad de zonas de remachado.

-¿Que es fuselaje? le pregunto

- El cuerpo del avión. Nosotros decimos: Esa chica tiene buen cuerpo, nosotros decimos Tiene buen fuselaje.

Son innumerables como usted ve, son cantidades impresionantes de fotografías. Entonces cuando yo hago un cuadro distribuyo alrededor de la tela todas las fotografías ... voy a hacer la trompa del Pucará y pongo 10, 15 fotos de la trompa, y pinto la trompa. Saco esa foto y pongo 10, 15 fotos de la cabina y hago la cabina.

Y ¿cómo hacía yo para comprobar? Porque uno se marea con tanto detalle, llega un momento en que se satura del cuadro, y no ve cosas que son importantes. Entonces qué hacía yo: los invitaba a los mecánicos del avión cuando pintaba en la FA, y les decía: un paquete de cigarrillos de regalo a quien descubra un error. Entonces se ponían los cabos, cabos principales, los cabos primeros, acá tá acá tá, se olvidó la tapa del tanque de combustible. Ah! Te ganaste una etiqueta de cigarrillos y yo me gané un cuadro sin críticas cuando lo entregaba. 24 De esa manera con el examen, porque son hipercríticos los pilotos, o los mecánicos, el personal aeronáutico cuando ve un cuadro mío automáticamente empieza a ver si está todo porque todos los pilotos cuando van a volar revisan el avión. Empiezan por la escalera de subida, dan toda una vuelta alrededor del avión revisando tren de aterrizaje, tanque, punteras de plano, superficie, móvil, todo, todo, todo inspeccionan. Inspeccionan el cuadro como están habituados a inspeccionar el avión. Ven un avión y ya lo están inspeccionando. Y ven si tiene todo. Entonces por

Iluminuras, Porto Alegre, v. 14, n. 34, p. 324-354, ago./dez. 2013 
eso mis cuadros están llenos de detalles de elementos del avión. Tengo que ser hiper realista.

En el análisis anterior, el cuerpo del piloto relatando también con palabras y representaciones gráficas, tomaba el lugar de la acción, de la dinámica. Ahora nos encontramos con el material primordial de la acción del piloto, el avión, al que Martínez le aplica un tratamiento similar al que se le da en la rutina aeronáutica. Entonces los cuadros de Martínez muestran el avión, apenas al piloto dentro de su casco en la carlinga, y no muestran pero contienen, por sus observaciones, a los técnicos y a los suboficiales (la mayoría de los cuadros son acciones de oficiales cazadores, y los suboficiales implicados en la misión de un C-130 o KC-130 Hércules no pueden verse en el interior de la "chancha". Los técnicos y los suboficiales aprestan al avión para volar y en los cuadros de Martínez lo aprestan para ser vistos como máquinas de imaginación plausible en cada acción de combate.

Pero si bien los técnicos y eventualmente los pilotos corrigen el cuadro casi terminado, es el pintor el que da el último toque, porque él sabe cómo utilizó las fotos para presentar el material aéreo, lo cual es otra construcción que parte de pero disiente con la fotografía. Martínez me explicaba que los impresionistas entraron a competir con la fotografía (hasta entonces en blanco y negro) mediante el realce del color. "Ellos se refugian en el color, no pueden competir con la forma de la fotografía". Pero la fotografía tiene distintas tonalidades que provienen de la luz, natural y artificial. La imagen no es uniforme y, en una escena con aviones de combate, el problema es aún mayor dada la propia pintura del avión y su premeditada mimetización con el suelo y con el cielo.

Entonces ¿qué hago yo? Cuando yo fotografío un avión, ... y diafragmo para la luz que tiene en el lomo del avión toda la panza me sale negro y sombras, y no hay detalle. Entonces yo tengo que sacar otra fotografía y diafragmar, abrir el diafragma para que me salgan los detalles de la panza que están en la oscuridad. Pero cuando me salen los detalles de la panza el lomo del avión es un yeso blanco sin detalles, entonces yo saco, dos veces fotografío a los aviones, porque es imperfecta para mí la fotografía, no tiene detalle en sombra ni tiene detalle; en una sola foto no salen. Necesito dos fotografías, pero cuando hago el cuadro hago un sólo cuadro con el detalle de la fotografía con el lomo y de la segunda, entonces yo lucho contra la imperfección y le gano a la fotografía, en detallar algo que la fotografía no puede hacer. Entonces yo no hago como los impresionistas que le escapan al combate con la fotografía y le gano haciendo detalles buenos en sombras y detalles buenos en luces. Y mi fotografía tiene los buenos detalles de la parte superior y de la parte inferior de los aviones, que es algo que en una sola foto no se puede obtener. Es una imperfección de la fotografía. Los maestros de la pintura en su época no la pudieron porque no tenían fotografía en color, o no tenían

Iluminuras, Porto Alegre, v. 14, n. 34, p. 324-354, ago./dez. 2013 
tiempo, o no supieron interpretar al no ser fotógrafos esa debilidad que tenía la fotografía.

Aunque hay algunos cuadros con aviones solitarios, la mayoría reproduce escenas de combate; sólo unos pocos se dirigen a la acción.

el problema es la oportunidad. Generalmente el buen fotógrafo es aquel fotógrafo que tiene la oportunidad y se mueve con una velocidad tan grande que agarra el momento justo o casi justo. Yo no tengo problema. Me siento en mi tablero de dibujo y elijo el momento que se me da la gana, el mejor de todos, y lo creo, lo hago con los elementos que integran la fotografía. Todos los elementos que integran una fotografía yo los pongo, los ubico en el momento necesario que se necesite recordar. Por ejemplo, todos los aviones (pintados lo) son después del ataque para que se vean los efectos de su ataque, en cambio las películas de los ingleses están filmadas desde los buques a los aviones cuando vienen, pero no se sabe qué pasó después, porque el fotógrafo estaría muy ocupado escapando de las explosiones, entonces no puede retratar lo que pasó después. O hay fotografías de la Coventry a punto de hundirse pero no están los aviones que ocasionaron ese hundimiento.

Exequiel me explicó que los cuadros con más valor para los aeronáuticos son aquéllos en los que el piloto acaba de cumplir su cometido o está en plena acción. Se trata de aviones que apenas dejan atrás a la nave dañada y humeante o estallando; a veces el avión está en el centro de la escena y la fragata ligeramente desplazada; en otras el avión acaba de atacar y está del lado derecho o izquierdo del cuadro, como saliéndose de él.

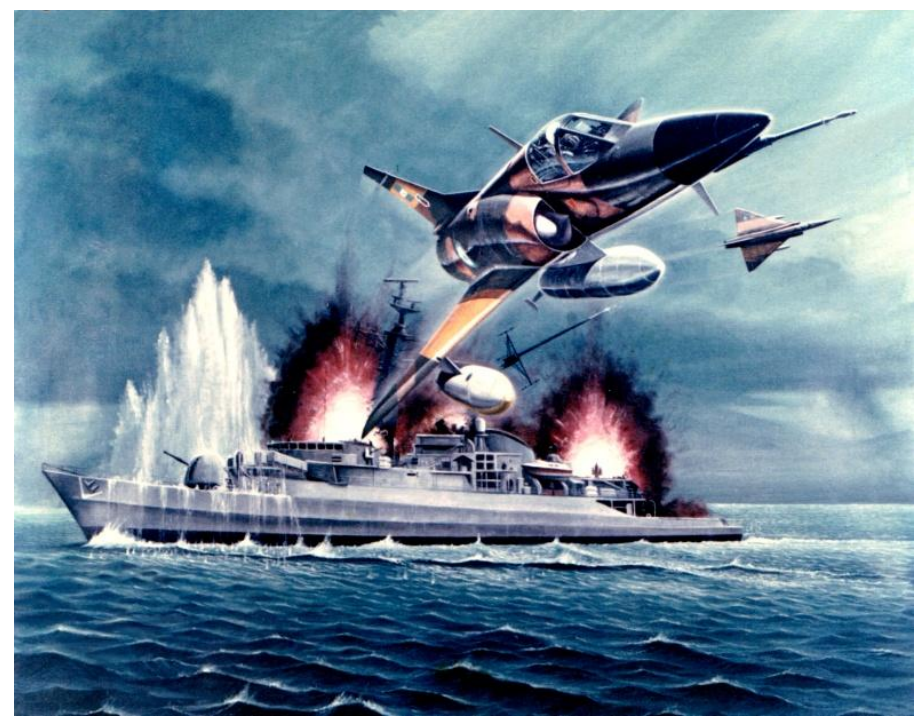

M-V atacan a HMS Ardent (Martínez en Matassi1994:73). 
Pero aunque se trata de un instante, la escena o el corte, casi fotográfico, corresponde a una misión completa y de mayor duración, que debe contener, por así decirlo, los puntos suspensivos del antes y del después que la articulan con las otras escenas de la misión, de la sucesión de misiones y de la jornada. Martínez logra esos puntos suspensivos imprimiéndole movimiento a la escena, direccionalidad, intención. Por eso él entiende que la pintura supera a la filmación.

\begin{abstract}
Hay escenas en videos de los ataques y se sienten las explosiones, ta ta ta ta ta, cuando están haciendo los ataques, pero no hay una imagen completa y detenida como para que uno pueda, porque el video le da el movimiento pero no nos da el detalle del ataque. Lo tenemos que congelar para poder estudiarlo. Ah, acá está, este es el buque fulano de tal, este es el avión tal cosa, tenía tanques /.../ eran dos aviones, eran tres aviones, aquí vira hacia la izquierda. En un video no nos da, nos da todo el dramatismo de la acción pero no nos permite identificar a cada uno de los combatientes con detenimiento. La fotografía nos permite el detenimiento pero no nos da la acción. En cambio el cuadro compagina un poco de cada cosa. Yo puedo dar con el pincel, yo puedo hacerle estelas al avión, yo lo puedo colocar en una manera tal que se vea el movimiento de la acción que a lo mejor no podemos poner un fotógrafo justo en el mar arriba de una balsa desde el ángulo más fotogénico para la escena. No había fotógrafos .
\end{abstract}

Falta todavía un ingrediente que fue para Martínez, como para la Fuerza Aérea, una novedad: el mar, jurisdicción de la aviación naval. Exequiel no sabía pintar mar, igual que la Fuerza no debía volarlo ni atacar blancos navales.

Éste creo que es uno de los que mayores exigencias que tuve en pintura de mar, me obligó a hacer un cuadro de mar, porque siempre pintando cielo, un pintor de fuerza aérea pinta cielo, pensé que iba a ser una guerra aérea pero fue una guerra aeronaval y tuve que aprender a pintar mar, que nunca había pintado.

¿Qué implicaba “pintar mar”? Lejos de una masa homogénea en tonos de azul, Exequiel traducía en sus cuadros el estado de ánimo océanico: mares encrespados o calmos, costas o mar abierto, acantilados y estrechos. Pero además el mar se modificaba conforme a la perspectiva. A veces el pintor se ubicaba casi al ras del agua y debajo de los aviones, a veces inmediatamente detrás de las aeronaves y a veces muy por encima de toda la escena. 


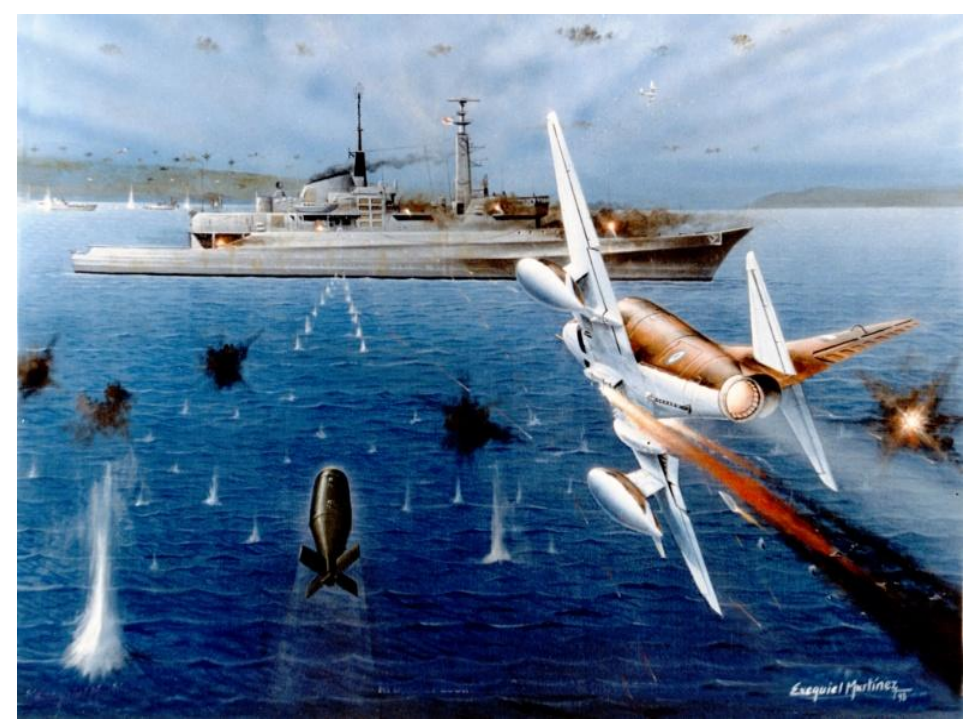

Martínez 2012a. Ataque de 1er Ten. Guadagnini, 23 mayo 1982.

Pero el mar no estaba virgen ni formaba parte de un paisaje natural; no era un telón de fondo sino la caja de resonancia del combate; afectado profundamente por la acción bélica, el mar aparece bombardeado y surcado por la Task Force británica. Exequiel debía reproducir siluetas navales que correspondieran al modelo de fragata o de buque involucrado en cada escena, dejando en claro una idea de la magnitud desigual del ataque aéreo a semejantes buques y la certidumbre histórica de la acción bélica. Los proyectiles emitidos desde los buques debían dar la imagen de un asedio constante a los pequeños aviones que se aproximaban. El ataque a la HMS Coventry del 25 de mayo es una imagen invertida que procede de un original fotográfico en blanco y negro tomado desde la HMS Broadsword. Martínez procede a pintar la imagen simétrica ubicándose detrás y por encima de los aviones argentinos, y a las dos fragatas como sus objetivos. 


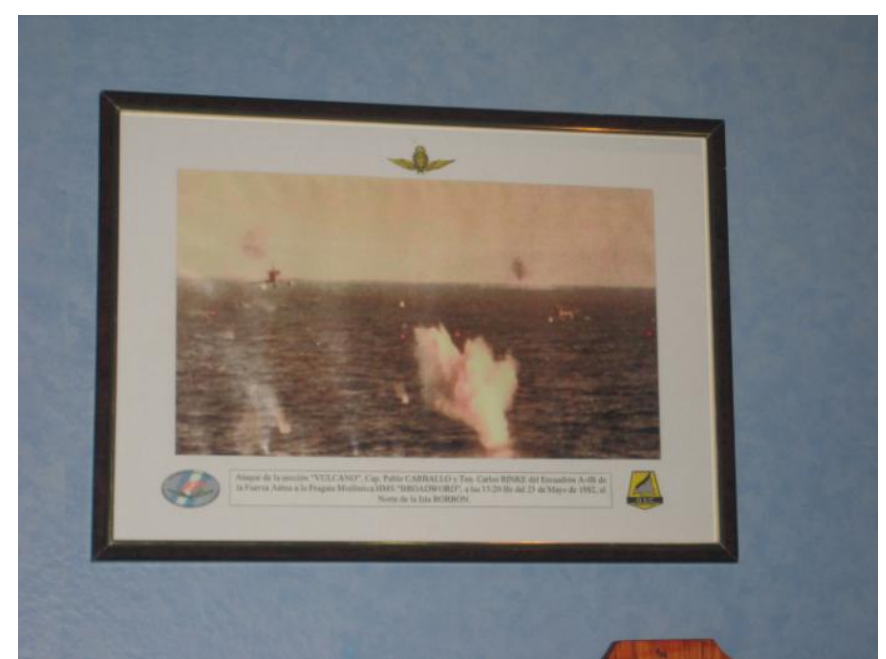

Foto Sala Malvinas, EAM, Córdoba. Ataque escuadrilla Vulcano (A-4B) tomada desde fragata HMS Broadsword. Los dos puntos en el horizonte rasantes son los A-4B de los pilotos Velasco y Barrionuevo.

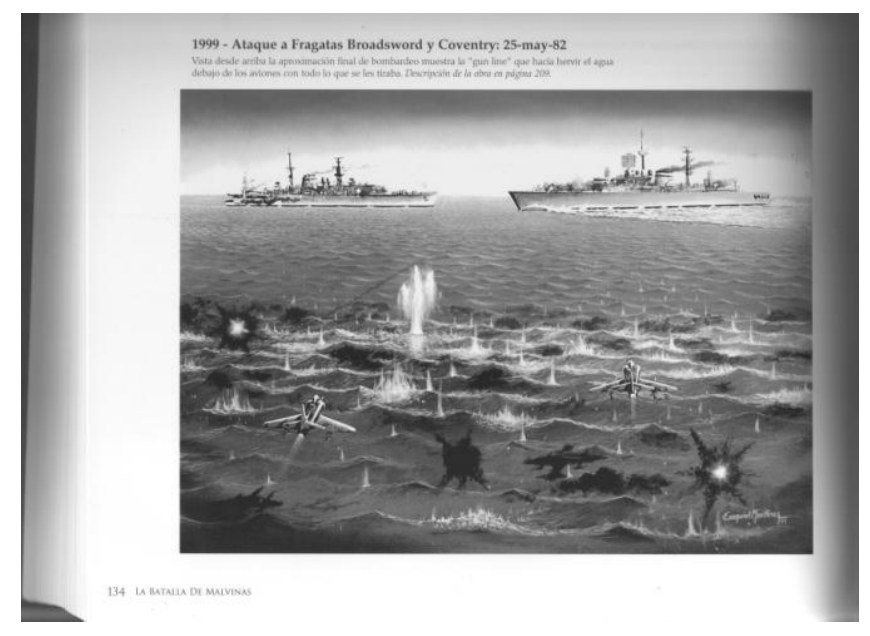

Martínez en Matassi 1994:86. Foto en B/N del cuadro Ataque a la Broadsword y Coventry, 25 de mayo 1982.

Todo este despliegue debe haber significado un gran esfuerzo de imaginación realizado a partir de lo aprendido por el pintor desde su alistamiento en la EAM hasta que dejó los aviones de combate para dedicarse a los helicópteros y, luego, a la aviación civil en este mismo vehículo. Exequiel nunca piloteó ni un A4B, ni un A4C, ni un MIII ni un MV, ni Pucará ni Boeing o KC 130, pero podía imaginar, desde sus cuadros, las acciones concretas con la mentalidad de un piloto de combate, de intercepción o de transporte. No era éste un ejercicio de inspiración individual; Martínez se encuentra en permanente elaboración de la plausibilidad de sus representaciones icónicas a las que convertía en una experiencia compartida uniendo las circunstancias bélicas con la 
postguerra, cuando Martínez pintó sus cuadros sobre Malvinas. Una vez concluidos, convergían en sus pinturas, además de las ideas del pintor, muchos otros personajes.

Veamos ahora qué sucedía con aquella plausibilidad aeronáutica cuando los protagonistas miraban los cuadros. Siempre que les pregunté a quienes habían sido "retratados" en cuerpo o avión si recordaban la escena de ese modo, me contestaron: -Y, no sé, yo estaba ahí adentro", señalando la cabina. Y aunque Exequiel me dijo que algunos se sorprendían diciéndole -Sí, así era, exactamente!, creo que la relación de plausibilidad entre la imagen y su experiencia recordada estaba en otra parte. Volviendo al cuadro de Callejo, es claro que le encantó y hasta pudo reconocer cómo se veía el misil. Pero para que este reconocimiento se produjera no hizo falta que el ojo del pintor estuviera puesto en el mismo sitio que el ojo de su protagonista en 1982.

Para Pío Matassi, artífice bastante activo de la imagen pública de la Fuerza Aérea posterior al 14 de junio, se trataba de

\footnotetext{
"sacar de esa guerra, de ese esfuerzo, el máximo provecho. Ese provecho se saca porque da muchas enseñanzas operativas una guerra. La experiencia vale mucho porque es propia. Salir a la cancha, al ruedo. Eso lo sabe únicamente el que sale. ... la vivencia tiene un valor muy grande".
}

Y para él, operando desde su oficina de la Comisión de Análisis, Historia y Evaluación de la Guerra de Malvinas, los cuadros de Martínez servían a estos fines ya que recurrían a "infinidad de elementos de juicio, por eso tienen valor sus cuadros, porque son lo más parecido a la realidad. -Más que la foto?, le pregunté. -Acá, por ejemplo, nadie puede sacar esta foto. Yo digo que éste es un ataque que únicamente Dios lo ha visto así. Este es un ñato que está a unos 20 metros de altura más arriba de los aviones, en una tribuna". 




Ataque al HMS Invincible tomado desde K-C130 reabastecedor (Martínez 2012a).

Se refería a la misión contra el HMS Invincible, que en verdad es la pintura sobre la base de una fotografía tomada por la tripulación de uno de los dos KC-130 que abastecen a los dos Super Etendard de la Armada, y a los cuatro A-4C de la Aeronáutica. Pero la fotografía está en blanco y negro, y probablemente es verdad que nadie, excepto un pintor, puede recrear aquella fotografía de manera tan clara y brillante. La principal diferencia entre foto y pintura no es, sin embargo, el color, sino la nitidez con que se ven los aviones, que en la fotografía se asimilan a los grises del cielo sobre un mar en tonos similares.

En 2009 el entonces Cdro. Daniel Gálvez (ind.Chango) me acompañó a la Sala Malvinas de la EAM en el primer piso del Cuerpo de Cadetes. En el rincón izquierdo opuesto a la entrada, hay algunos cuadros de Martínez. Gálvez apuntó a uno y me dijo: Ese soy yo cuando pasábamos sobre Puerto Argentino.

“... los que están volando son Carballo y yo, de hecho figura en la inscripción. Este pasaje no fue ninguna misión sino un reconocimiento de la isla por parte de Carballo, ya que los jefes de escuadrilla debían reconocerla. Como yo ya había estado con Palaver, mi jefe de escuadrilla y Guadagnini en otros vuelos, me eligieron para acompañarlo. Esta es la primera vez que Carballo vio la isla y como se ve en el cuadro, sobrevolamos Puerto Argentino" (Gálvez, email 30 de marzo, 2012, 20:48hs). 
Estábamos en la oficina "Malvinas" del Edificio Cóndor conversando con el Cdro. (R) Ernesto Ureta (ind. Taca) sobre el ataque al Invincible, sentados en los sillones adelante de su escritorio. En la pared detrás de su silla de trabajo hay un cuadro con una escena inmediatamente posterior al ataque. En varios tramos de su relato, Ureta apuntó al cuadro para referirse a su acción, al reconocimiento de su otro sobreviviente de A4C, el entonces alférez G.Isaac, y sobre todo, para "demostrar" que el buque atacado era, en efecto, el Invincible. Ahora bien. Si en sus relatos posteriores a los oficiales de inteligencia de la Armada y a sus camaradas y superiores, el Taca e Isaac (y seguramente los dos pilotos de Super Etendard CC. A.Francisco y TN L.Collavino) afirmaban haber atacado el mismo tipo de buque que el que se les había instruido como objetivo, un portaaviones, era bastante lógico que el buque representado por Martínez en su cuadro fuera precisamente el Invincible. Es interesante que Ureta empleara el cuadro como una prueba que respaldaba su memoria, como una fotografía tomada por un tercero no involucrado en la misión argentina. La "prueba del cuadro", en este caso, es superlativa porque contrasta con la ausencia de contraparte. Gran Bretaña ha sostenido que fue el HMS Avenger el que derribó a los dos A-4C, aunque sus versiones fueron bastante variables. Sin embargo, la realidad es que el Invincible fue apartado del teatro de operaciones, demoró en exceso su vuelta a Inglaterra, y toda información verbal y visual sobre su estado fue absolutamente vedada. Las versiones suministradas en los cuatro interrogatorios (los dos pilotos navales y los dos pilotos aeronáuticos) son coincidentes, y en todas aparece nítidamente la pista del "porta aviones". Pero ninguno de los cuatro sobrevivientes tendría la posibilidad, como sí la tuvieron otros, de "redondear" lo vivido con sus contendientes directos, precisamente por la negativa oficial de Gran Bretaña a su reconocimiento. Entonces, la identidad del cuadro al que apuntaba Ureta aquella tarde, cobraba un nuevo vigor ${ }^{3}$.

Supuse, por formato y perspectiva, que el cuadro era de Martínez (como las muchas reproducciones de otras escenas que hay en la antesala de la oficina, y en las salas contiguas de la dependencia), pero Ureta me corrigió. Pertenecía a Elvira Salvadore, su esposa, quien venía tomando clases de pintura en su estadía en el Perú. "Elvi”, como firmaba, lo había pintado tomando por modelo al de Martínez, y se lo

\footnotetext{
${ }^{3}$ El príncipe Andrew, que para entonces se encontraba a bordo del Invincible, declaró en 2012 a un periodista que debió tirarse cuerpo a tierra en circunstancias de ataque aéreo.
} 
había regalado a su marido el 30 de mayo del 2002, el $20^{\circ}$ aniversario de la operación, durante su agregaduría aeronáutica en Lima. Este "cuadro-ejercicio" no hubiera pasado indemne la prueba de técnicos y pilotos; faltaba "la probe" para reabastecimiento en vuelo del A-4C de Ureta, el avión en primer plano. Pero esta "falla" quedaba compensada por el respaldo familiar y afectivo que Elvira le brindaba a Ernesto en la conmemoración de la única operación combinada entre el CANA (Comando de Aviación Naval Aeronaval de la Armada) y aviones caza de la $\mathrm{FAA}^{4}$ en toda la contienda; de la pérdida de sus dos camaradas y de una osadísima misión cuyo blanco prefijado fue uno de los dos buques enemigos de mayor envergadura. Inspirada en la pintura de Martínez ${ }^{5}$, la pintora-esposa traía la misión de su marido al ámbito doméstico y lo respaldaba en su tesis acerca de la identidad del buque atacado. Ahora, su marido proyectaba el cuadro al ámbito profesional e institucional de su oficina en el Cóndor (donde proliferan los cuadros originales de Martínez) y lo señalaba como prueba de lo actuado. En este sentido, es doblemente lógico que el Taca se apoyara en aquel cuadro para demostrar que, efectiva y afectivamente, había dado con el Invincible.

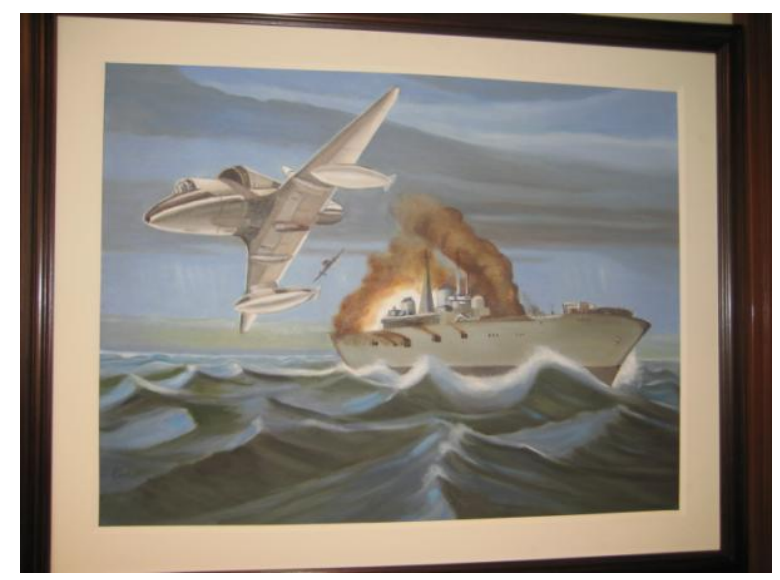

Ataque al Invincible, de Elvira Salvadore de Ureta (foto de la autora).

\footnotetext{
${ }^{4}$ La FAA prestó sus KC-130 reabastecedores a las misiones de A-4Q y SUE del arma Aeronaval de la Armada Argentina, a lo largo de todo el conflicto, además de transportar enseres, personal y armamento de las tres fuerzas. En este sentido, las misiones conjuntas fueron más, no así en la participación de ataques a blancos navales.

${ }^{5}$ En cuanto al original, Martínez pudo haber tomado sus impresiones iniciales de la operación en la cena de la misma noche del 30 de mayo, esto es, muy cerca del hecho. Los dos sobrevivientes de A-4C volvieron a Río Grande a dar su información a los interrogatorios de rutina, y luego regresaron a San Julián desde donde venían operando (Ureta, comunicación personal telefónica, 11 de abril, 2012).
} 


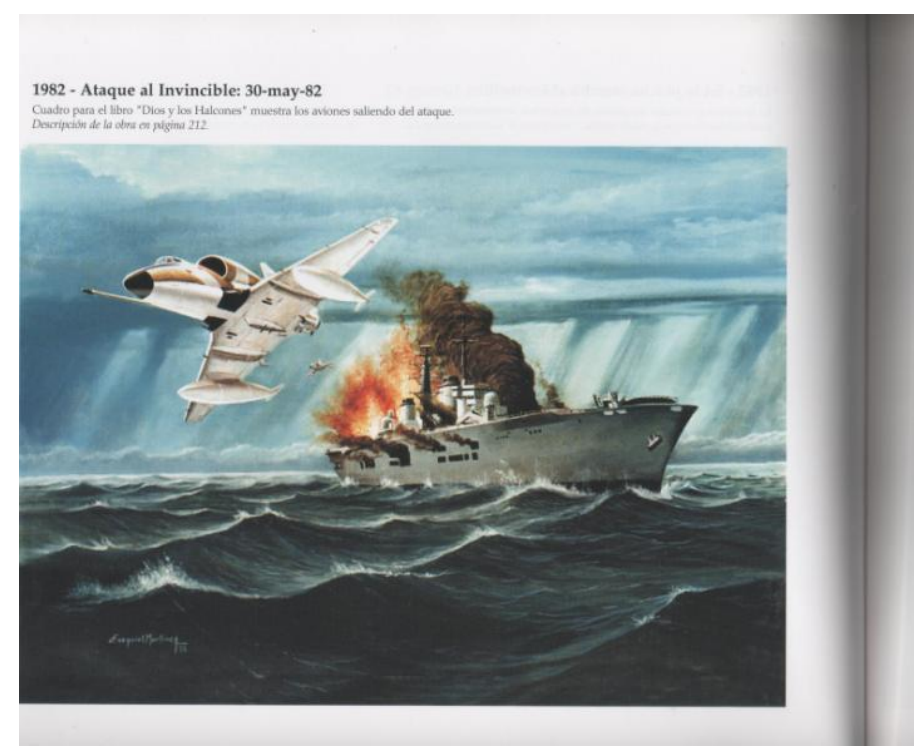

Martínez 2012a. Ataque al Invincible

Cuando fui a visitar a Bibiana y a Alberto Filippini, piloto de A-4B en 1982, a su casa en el Gran Buenos Aires, entré por un breve pasillo que da al living; en la pared del pasillo vi "el Martínez" del ataque a la HMS Argonaut y la famosa antena rota atestiguando la proximidad del A4-B con su objetivo. Le pregunté al dueño de casa si era el cuadro de Martínez y me contó que le había encargado a un pintor amigo que se lo copiara, porque el original había estado en Villa Reynolds y luego se le había regalado al Presidente de la Nación Raúl Alfonsín, cuando visitó la V Brigada. Lo miré como preguntándole y preguntándome dónde estaría ahora que Alfonsín había muerto y que se trataba de una de las principales operaciones aeronáuticas en Malvinas.

En Reynolds hay varios cuadros originales de Martínez, y algunas reproducciones de sus pinturas, distribuidos por la unidad. Uno francamente impresionante es el de la sala de estar del Grupo Aéreo; ocupa una pared y muestra el cambio de A-4B por A4AR sobrevolando la brigada. Cuando quise sacarle una foto, flanquearon al cuadro el Cdro. Leonardo Carmona al mando de la V Brigada, y el Cdro. Ludueña, Jefe del Grupo Aéreo, y sucedieron mi toma con una explicación del sentido de la pintura.

Un dato que surge de este breve recorrido es que los originales de Martínez se encuentran en sedes institucionales, en las oficinas de jefaturas y en ámbitos especiales (salas de honor o museos) de las unidades aéreas. El tamaño, según Martínez me explicó, responde a 
"varias razones. Es proporcional al 4 x 3, medida conveniente a la capacidad visual del humano (dos ojos horizontales en el mismo frente). Se lo ve bien en una habitación chica, mediana y grande. Es proporcional a las páginas de los libros. Esta medida permite hacer bien los detalles con un pincel, más chico se pierde fidelidad. Es un tamaño que permite asegurar su permanencia; más grande se rompería fácil y más chico es fácil de llevárselo a casa.

Hubo también contratos especificando el tamaño, por ser éste el más adecuado (tanto) para una habitación de tamaño normal como para un museo" (Martínez, email 3 abril 2012, 10.18 hs.).

En vez, las abundantes reproducciones son bastante más pequeñas y algunas están enmarcadas. Los cuadros pertenecen, claramente, a la institución aeronáutica, y no a sus ocupantes circunstanciales. Tampoco se refieren, necesariamente, a las acciones bélicas de quienes están a cargo de dichas oficinas. Pero acompañan, casi siempre, las entrevistas filmadas o fotografiadas de los veteranos pilotos de Malvinas. Es que la mayoría de los reportajes periodísticos para $\mathrm{TV}$, tanto de redes nacionales como extranjeras, se hacen con algún cuadro detrás del entrevistado. Lo mismo sucede con notas en medios gráficos que incluyen una fotografía. Así, en 2010 el diario La Nación le dedicó dos páginas al entonces Comodoro Guillermo (Piano) Dellepiane (alférez en 1982). El cuadro que aparece en la foto de la nota, sin embargo, no corresponde ni a su reabastecimiento en vuelo de regreso el 13 de junio, ni al ataque al campamento británico de Monte Kent ese mismo día, comandado por el entonces Capitán C.Varela, sino al ataque al Invincible. Cuando le pregunté a Martínez qué cuadro se veía en la imagen, me contestó:

Hay como 5 ó 6 cuadros del ataque al Invencible para distintos lugares, puede ser de los últimos que fueron para Generación Malvinas y para la Casa del Gral. San Martín. También pueden ser de los del Cóndor si él estaba allí cuando lo entrevistaron.

En suma: hay cuadros y reproducciones desparramados por oficinas, antesalas, pasillos y corredores del Cóndor, las unidades, la EAM, la Escuela de Suboficiales, algunos aeropuertos, bases aéreas, despachos y jefaturas, sin contar con el Museo Aeronáutico de Morón que alberga a "los Génesis". Martínez cuenta que el comandante de la Fuerza lo invitó al Edificio Cóndor (sede de la comandancia de la Fuerza) y ante una pared vacía le preguntó qué podría hacer allí. Él se imaginó ante la misma situación de Miguel Angel Buonarotti en la Capilla Sixtina y entonces pensó en un Génesis aeronáutico, con tres murales de la historia de la aviación militar argentina. 
Posteriormente, pensó en tres paneles portátiles que pudieran circular por las unidades argentinas, para que los jóvenes se familiaricen, visualmente, con su pasado. Por eso tienen una función prioritariamente didáctica y sintética, que Martínez también aplicó a otros temas, como los peces del Chaco (lo que le valió una distinción de la Universidad Nacional de La Plata en 2010). No tienen el detalle de la acción individual pero reúnen varios cuadros ya pintados y los retratos en miniatura de las personalidades que van desde Newbery hasta el último conscripto clase 62 caído en 1982.

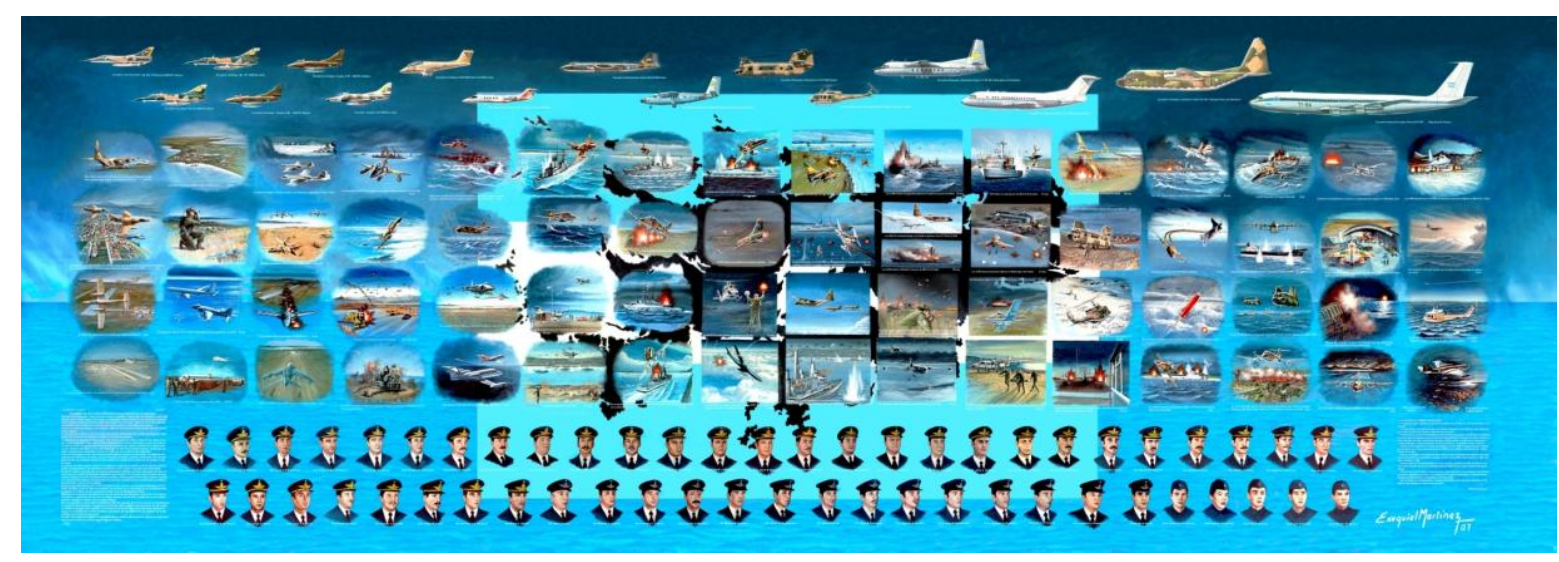

Génesis III - Martínez 2012a.

Pero en una de sus expresiones la pintura de Martínez tiene una función insustituible. Él dice que se siente mejor pintando aviones que personas, pero en su obra las personas son imprescindibles. En las escenas de combate, quienes llevan adelante la acción apenas aparecen y, en general, no pueden verse si no es a través de sus aeronaves. Pero en la sala de honor de la EAM hay cuadros de los 36 oficiales caídos en combate entre el $1^{\circ}$ de mayo y el 13 de junio. 


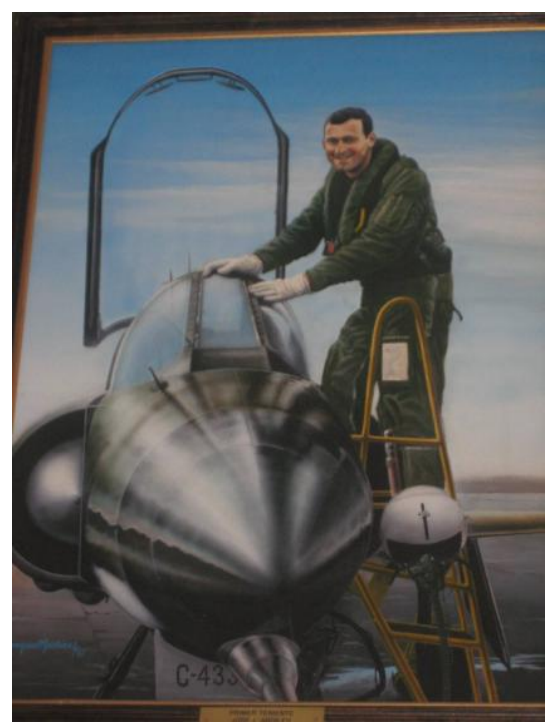

1er Ten. José Ardiles, fall. $1^{\circ}$ Mayo 1982 (Martínez en Sala de Honor, EAM, Córdoba; foto de la autora)

Las cuatro paredes donde se encuentran los cuadros casi tamaño natural de los caídos, generalmente con el avión detrás o al lado suyo, que volaban al momento de su muerte, circundan una caja de cristal con la banderas argentina que flameó en la Base Aérea Malvinas de Puerto Argentino, hasta el 14 de junio. Las imágenes de los caídos son, como las personas de Martínez, más rígidas que sus aviones, y suelen estar basadas en alguna foto provista por familiares. Estas fotos pintadas y necesariamente recreadas en actitud, color y tamaño son, sin embargo, un lugar de conmemoración en sí mismas. Cuando la promoción de Martínez cumplió los 50 años de egresada de la EAM, y los ya veteranos pilotos se reunieron de visita en Córdoba, hicieron su paso obligado por la Sala de Honor. Allí el representante de la Escuela que oficiaba de anfitrión, destacó que entre ellos estaba el autor de esos cuadros. Entonces Martínez pasó al frente y en unas pocas palabras contó cómo había pintado a cada uno de los caídos; se levantaba muy temprano y conversaba con ellos mientras los iba trazando en su tela y les auguraba emotivamente a sus retratados, que pronto se reuniría con ellos a tomar mate y a seguir charlando. La recepción conmovida de su mensaje por parte de varios de los presentes demostraba la comprensión empática con el piloto-pintor. Las mismas pinturas, sumadas a una foto y a los datos biográficos básicos y las circunstancias en que cayeron, se encuentran reproducidas en varias unidades aeronáuticas. En la sala de honor que está a un costado del Museo de la Vta Brigada Aérea de Villa Reynolds, San Luis, se exhiben los nueve oficiales de A-4B que murieron en combate. 


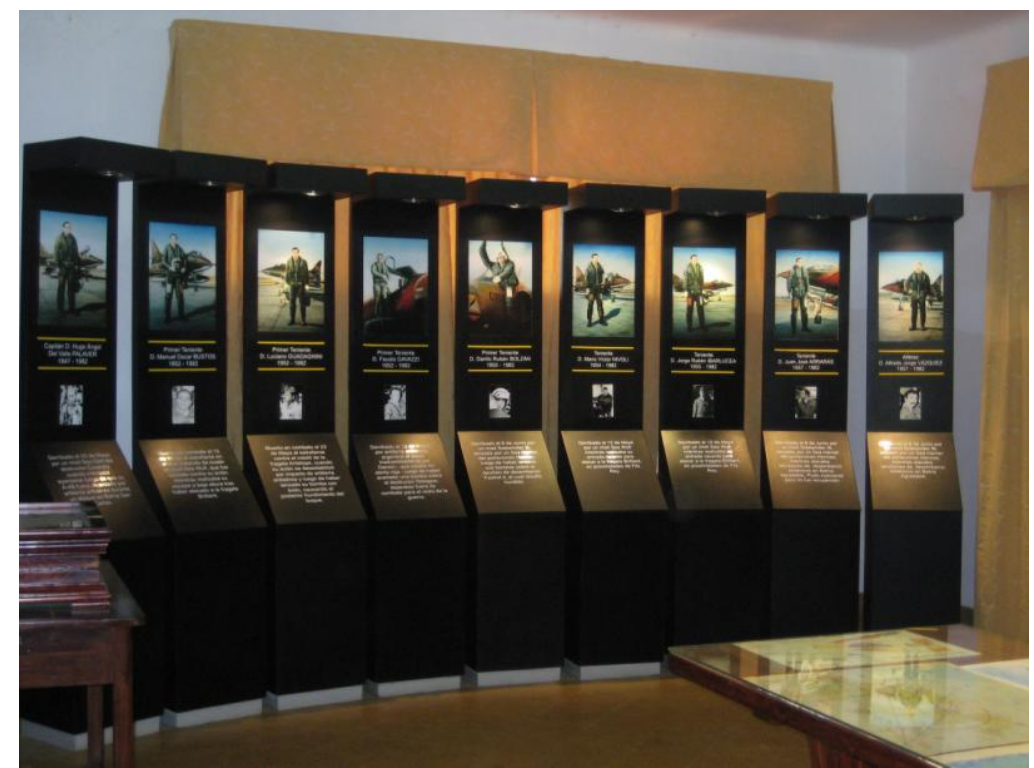

Sala de honor, Museo de Brigada 5 de Caza, Villa Reynolds, San Luis. (Foto de la autora)

Es cierto que el Brigadier Ernesto Crespo, comandante de la Fuerza Aérea Sur operativa en Malvinas desde las unidades patagónicas y las dos bases aéreas en las islas, luego comandante en jefe de la Fuerza Aérea, le encomendó a Martínez pintar para la posteridad las acciones de sus pilotos. En verdad, no creo que hiciera falta que se lo pidiera tratándose de Martínez, una personalidad que, como me confió Matassi, "Es piloto de helicóptero, antes era de aviones, un artista, un bohemio; por eso se fue de la Fuerza Aérea, acá no quería lola; es un gran patriota, una capacidad fuera de serie, pero no le gusta que nadie lo mande" (1991).

Ciertamente, es la de Martínez una pintura institucional. Por muchos años la Fuerza compró sus obras para albergarlas y exhibirlas, para regalar a personalidades e instituciones de la Argentina y del exterior, como sucedió con el extraordinario mural por los 50 años de la $\mathrm{OACI}^{6}$ y hasta para tapar una mancha de humedad. Pero sus pinturas excedieron ampliamente los pasillos y las salas de la institución, como también excedieron en fama las correspondientes a las acciones de 1982 a su serie histórica. Los cuadros de Martínez se convirtieron en la imagen en movimiento de una serie discreta de escenas de combate, cierto que de los exitosos. En efecto, su historia de la Batalla

\footnotetext{
${ }^{6} \mathrm{http}: / /$ www.exequielmartinez.com.ar/autor_a.htm
} 
Aérea de Malvinas de la Fuerza Aérea Argentina es una historia en fragmentos que no se pintó cronológicamente y que tampoco contiene la totalidad de lo ocurrido entre el $1^{\circ}$ de mayo y el 13 de junio del '82. No hay aquí eyecciones ni paracaídas; no hay aeronaves argentinas abatidas ni humeantes. En cuanto a sus caídos de la Sala de Honor, podría decirse que están por partir a una misión o, mejor aún, acaban de regresar de ella. Tomados en conjunto los cuadros de Martínez cuentan la Batalla Aérea de Malvinas, pero cada cuadro cuenta, en una toma, muchas historias: la de los contendientes, la de las escuadrillas, y la de las misiones de la jornada e, hiladamente, las del sistema de armas y las de la Fuerza en su conjunto, permitiendo visualizar las razones por las cuales los pilotos argentinos fueron objeto del reconocimiento internacional. Cada cuadro, bien mirado, contiene una unidad operativa: una escuadrilla o una sección, y aún cuando sólo aparece un piloto, se sabe que su soledad pende de la de su grupo, aún cuando una parte hubiera caído.

Tanto por lo que se representa en las pinturas como por la interacción que suscita su presencia a través de comentarios, explicaciones y miradas, los cuadros de Martínez generan una relación particular entre el presente y el pasado.

Nunca conseguí que Martínez me respondiera a mis preguntas sobre cuadros específicos, hablándome de sus cualidades artísticas. Ni él ni sus "retratados" hacían referencia al color, los trazos, la perspectiva. Como si obedecieran a un impulso fundamental e inevitable, pasaban a describir la escena y se internaban en los datos básicos del combate que justificaba a esa pintura. Así, ante mi pregunta por el cuadro que respaldaba a Dellepiane, después de un par de datos sobre cómo ubicar el contenido del cuadro, Martínez prosiguió:

\footnotetext{
Sabés que gritaba el Pianito ${ }^{7}$ cuando volvía con los tanques agujereados --" Chaco"' "Chaco" donde esta' me tiro me tiro-- El nombre de guerra que tenía mi helicóptero en San Julián era "Chaco" y yo iba a su encuentro. Le dije al radar de SJU que marcara el lugar en la pantalla del radar y me llevara allí. Como no íbamos a poder volver yo bajaría la balsa para que los rescaten al Piano y después yo amerizaba solo y me subían a mí.

Íbamos a perder un helicóptero pero ganábamos un piloto de A-4 que valía oro. Afortunadamente encontró la Chancha y lo trajeron. Yo volvía abajo de ellos casi tanques en cero.
}

\footnotetext{
${ }^{7}$ Diminutivo del indicativo de G.Dellepiane PIANO, probablemente por su minoridad aérea. Dellepiane era alférez. Los pilotos que conocí que se desempeñaron como alféreces en la guerra, se auto-adscribían como "plumíferos", no como "halcones" o pájaros totalmente formados. Malvinas terminó siendo para ellos un doble bautismo: el común con la Fuerza Aérea, y el de oficiales recién salidos "del huevo".
} 




Martínez 2012a. El regreso del Piano, 13 de junio, 1982.

En este sentido y sólo en este sentido, uno podría concederle al pintor, que

Yo de esto no sabía nada. Cuando la revista 7 Días en una oportunidad publica "Hiper realismo. Nueva corriente en la pintura bla-bla-bla de pintores famosos en la República Argentina" pintores que venían efectuando este tipo de pinturas en la Argentina, Fulano, Mengano Zutano. En temas aeronáuticos: Exequiel Martínez, me consideraron un hiper-realista. Yo no tengo escuela. No sé, yo hago lo que tengo necesidad de hacerlo. Y me encasillaron dentro de un realismo que debe ser el tipo de pintura que entre los pintores se dividen en sus clases. Es la necesidad de expresión que tiene el medio aéreo, representar a sus aviones con un realismo muy grande.

Cuando le dije en su nueva residencia, que Unquillo era un pueblo de pintores, me los nombró uno por uno (Carlos Alonso y Eneas Spilimbergo son los más notorios), pero cuando quise saber si se daba con ellos me contestó gestualmente, como diciéndome que hacían cosas distintas.

Es que los pilotos que los ven al pasar, o que se detienen a verlos en una sala, que conviven con sus cuadros porque van a otra oficina donde forman parte del decorado o porque fueron apostados en el despacho que a cada quien le toca ocupar ese año, no admiran sus cuadros como obra artística; en todo caso los comparten, como si los admiraran desde adentro, incluidos en sus escenas. Apenas se asoman fuera cuando alguien, como yo, se refiere a ellos; quienes conocen "la historia", lo que sucedió en la ocasión representada, no necesitan explicaciones. Entonces sí es necesaria la apreciación, pero no del cuadro sino de la acción representada, del combate, y así la escena empieza a hilarse desde un instante en un segmento, del segmento en la misión, de los que fueron en los que volvieron, y desde ese ataque hasta el eventual 
hundimiento. Con agregado sobre agregado el cuadro se ha convertido en una unidad mayor que respalda la historia como relato y recuerdo de la experiencia, del mismo modo que los cuadros respaldan a los pilotos en su presentación visual ante los medios de prensa y los documentales. La historia del ' 82 sigue vigente porque se renueva en los comentarios no técnico-artísticos pero sí técnico-aeronáuticos a los cuadros de Martínez, haciendo circular dinámicamente la relación entre el cuadro-imagen de una escena vista por contadísimos actores, la experiencia del combate vivida por los protagonistas y por sus camaradas conocedores e iniciados, y la experiencia narrada que recibimos los legos.

El concepto de plausibilidad nos permite comprender, en el caso de los cuadros de Martínez, el proceso por el cual una serie de imágenes se ha ido incorporando al "imaginario" (de imagen) aeronáutico militar y a sus simpatizantes civiles. Sin embargo, el término tiene una limitación porque no alcanza a dar cuenta del aspecto experiencial del cual resultan los cuadros: experiencia aeronáutica de Martínez; experiencia de combate del/os piloto/s representado/s; experiencia de pilotos y mecánicos en detectar fallas y faltas en un avión presto a partir. Cuando Ureta me explica que una vez vio un cuadro sobre el ataque al Invincible que presentaba a Isaac haciendo una maniobra extraña, estaba constatando la implausibilidad de la imagen y por eso lo consultó a Martínez. Martínez rápidamente confirmó que no era un cuadro de su autoría: no por el estilo, ni por el tipo de pintura, sino por su falta de “aeronauticidad". Es esta plausibilidad experiencial que, ofrecida por el pintor, se va implantando en la comunidad aeronáutica (técnicos, suboficiales, oficiales y empleados civiles)y en sus espectadores legos. Entonces, y gradualmente, supongo que todos ellos les fue pasando algo de lo que me pasó a mí. Cuando Oscar Aranda Durañona, conversando conmigo en su oficina de la Dirección de Estudios Históricos me mencionó el riesgoso rescate protagonizado por el 1er ten. M.N.Uriona en la Isla Borbón, yo inmediatamente recordé el cuadro en amarillos de Martínez, y como una alumna de escuela se lo mostré en una versión compendiada que llevaba encima, de Matassi y Martínez (1994:93). Después de todo, Exequiel tenía razón: los pintores hacen la historia ...visualmente hablando. 


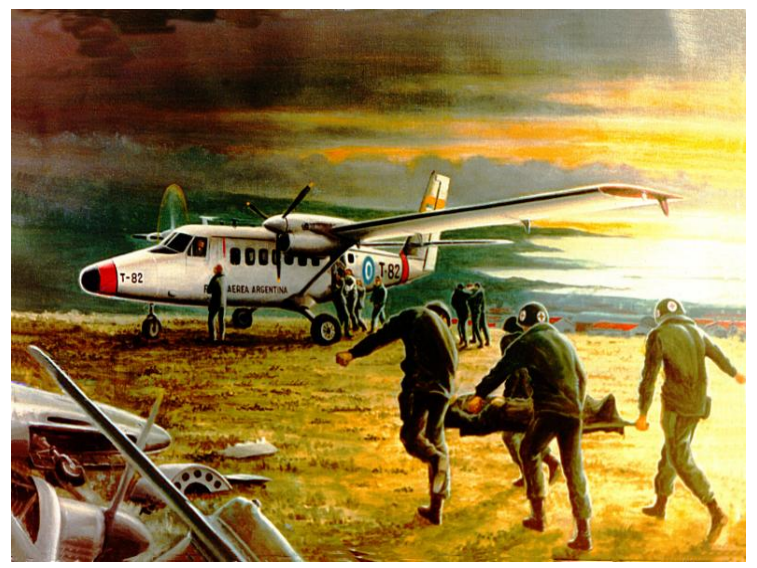

Martínez, 2012a, rescate en Base Aérea de Isla Borbón.

\section{Referencias}

CAMPOS, Alfredo de la María ."Galería de Arte” en Aeroespacio. 561: 59. Set-Oct, 2004.

CARBALlO, Pablo M., Dios y los Halcones. Buenos Aires: Editorial Siete Días. 1983.

Dirección de Estudios Históricos de la Fuerza Aérea Argentina, Archivo Malvinas, Edificio Alas, Buenos Aires: Argentina.

FABIAN, Johannes. Remembering the Present. Painting and Popular History in Zaire. Berkeley: University of California Press. 1996.

GARCÍA, Carlos Adrián. "Galería de Arte” en Aeroespacio 560: 59. 2004

GARCÍA KUEN, J.M.. Pinturas, Gente, 1982

GINZBURG, Carlo. The enigma of Piero. Piero della Francesca. The Baptism. The Arezzo Cycle. The Flagellation. London: Verso. 1985

GUBER, Rosana "Bautismo de fuego y gracia de Dios". Tabula Rasa 6:221.262 Facultad de Ciencias Sociales, Pontificia Universidad Javeriana, Bogotá, Colombia. ISSN: 1794-2489. 2007. Versión digital: http://redalyc.uaemex.mx/redalyc/pdf/396/39600610.pdf http://www.revistatabularasa.org/numero_seis/guber.pdf

MARTÍNEZ, Exequiel F. Página web http://www.exequielmartinez.com.ar/

MARTÍNEZ, Exequiel F. “Galería de Arte” en Aeroespacio 563: 59, 2005.

MARTÍNEZ, Exequiel F. "Lámina central: Aviación Argentina (1867-1945)” en Aeroespacio, Colección Aeroespacio n 14.2005

MARTÍNEZ, Exequiel F. Aviación Argentina en el arte de Exequiel Martínez. Buenos Aires: Editorial de Arte. 2012a. 
MARTÍNEZ, Exequiel F. en DI PAOLO, Jorge. "Un día para recordar”, en Aeroespacio 601602: 34-37. 2012b

MATASSI, Pío. Probado en combate. Buenos Aires: Editorial Halcón Cielo. 1994.

MORARD, Marcelo. “Galería de Arte” en Aeroespacio, 565: 59. 2005.

O’MILL, Allan. “Galería de Arte” en Aeroespacio, 567: 59. 2005

OSKI. "Galería de Arte” en Aeroespacio. 569: 53. 2006.

RODRÍGUEZ ARGAÑARAZ, Jorge Marcelo."Galería de Arte” en Aeroespacio 562: 59. 2004.

VASALLO, Juan Esteban.“Galería de Arte” en Aeroespacio 564: 59. 2005

Recebido em: 20/10/2013

Aprovado em: 03/11/2013 